\title{
Fine Needle Aspiration Cytology of Eccrine Skin Adnexal Tumors
}

\section{Devanand $\mathrm{B}^{1}$ and Vadiraj $\mathrm{P}^{2 *}$}

${ }^{1}$ Professor, VIMS Bellary, Karnataka, India

${ }^{2}$ Consultant Dermatologist, Bellary, Karnataka, India

\begin{abstract}
Background: Mastery of cytodiagnosis of adnexal tumors is challenging by virtue of the enormous number of individual tumors and their variant forms, the complicated nomenclature and the frequency of differentiation along two or more adnexal lines in the same tumor.
\end{abstract}

Aim : The present study is undertaken to assess the application of fine needle aspiration cytology in the diagnosis of eccrine skin adnexal tumors at all possible dermal and subcutaneous sites.

Material and Methods: This is a retrospective study of fine needle aspiration cytology of subcutaneous swellings over a period of two years from January 2009 to December 2010 in a tertiary care center. A total of 2400 cases of dermal and subcutaneous swellings, for which fine needle aspiration cytology was done with histological follow up, were included in the study. The aspirates were provisionally diagnosed as basaloid neoplasms of skin adnexal origin. The aspirates were further grouped into benign and malignant lesions based on cell morphology and correlation between cytological and histological diagnoses was assessed.

Results: Out of the 2400 cases of subcutaneous swellings, 20 cases were provisionally diagnosed as basaloid neoplasms of skin adnexal origin. They included 12 benign and 8 malignant lesions. The benign tumors were histologically diagnosed as spiradenomas(4 cases), nodular hidradenoma(4 cases), chondroid syringomas(2 cases), cylindroma( 1 case) and papillary eccrine adenoma(1 case). The malignant tumors were histologically diagnosed as sweat gland adenocarcinoma(4 cases), mucinous carcinoma of sweat gland(1 case), digital papillary adenocarcinoma ( 2 cases) and cutatneous adenoid cystic carcinoma ( 1 case).

Conclusions: Overall our study established that fine needle aspiration cytology is a very simple diagnostic investigation for neoplastic nodules in the skin.

Keywords: Basaloid; Benign; Cytology; Eccrine malignant; Skin adnexae; Tumors

\section{Introduction}

Eccrine glands are sweat glands which are appendages of epidermis of skin [1]. They secrete sweat, serve in the regulation of heat and contribute to general cutaneous homeostasis.

Tumors of eccrine glands are proliferations of eccrine ductal or glandular tissue or both in a hyalinized stroma, with lymphocytes as the main inflammatory infiltrate [2].

The present study is undertaken because fine needle aspiration cytology of skin lesions is not widely practiced. Also the literature contains very few reports about cytology of eccrine gland tumors and there is lack of adequate cytological diagnostic criteria of various entities.

These eccrine tumors have clinicopathological resemblance to other lesions like basal cell carcinoma,cutaneous leiomyoma, neurofibroma, malignant melanoma, subcutaneous metastasis from an internal malignancy, seborrhoeic keratosis, granuloma pyogenicum,cutaneous endometriosis [2-4].

Fine needle aspiration cytology (FNAC) is a simple, safe, quick, cost effective and informative procedure. FNAC can be used as complement to histopathology.

The aim of the present study is to utilise fine needle aspiration cytology as a diagnostic investigation for eccrine gland tumors at all possible dermal and subcutaneous sites.

\section{Materials and Methods}

The study was conducted in the combined departments of Dermatology and Pathology over a period of two years (2009-2010). Majority of the aspirations were performed in the department itself by cytopathologists. Prior to aspiration detailed history with physical examination of the lesion were carried out to assess the size, tenderness, plane of the swelling, and clinical evidence of malignancy. Fine needle aspirations were performed with 24 gauge needles and $10 \mathrm{ml}$ syringes to obtain scanty and cellular aspirates. Samples were smeared onto glass slides and fixed as necessary. Wet fixed smears were stained with hematoxylin - eosin ( $\mathrm{H}$ and $\mathrm{E}$ ) while air dried smears were stained with May-Grunwald-Giemsa (MGG) stains.

Amongst a total of 2400 cases of subcutaneous swellings aspirated during the study period, twenty cases of skin adnexal lesions with followup excision biopsy formed the crux of the study.

Each slide was reviewed by the cytologist who was blind to the original cytological and histopathological diagnoses.

*Corresponding author: Dr. Vadiraj P, No.18, KHB Colony, Gandhinagar, Near Women's College, Bellary, Karnataka, India - 583103, Tel: 08392 55187; E-mail: pyativadiraj@gmail.com

Received August 01, 2011; Accepted December 12, 2011; Published December 15,2011

Citation: Devanand B, Vadiraj P (2011) Fine Needle Aspiration Cytology of Eccrine Skin Adnexal Tumors. J Cytol Histol 2:129. doi:10.4172/2157-7099.1000129

Copyright: (C) 2011 Devanand B, et al. This is an open-access article distributed under the terms of the Creative Commons Attribution License, which permits unrestricted use, distribution, and reproduction in any medium, provided the original author and source are credited. 
The cytological smears were studied in the context of the available clinical findings. The aspirates were evaluated for cellular features, associated background and coexisting features as shown in the Table 1.

We also classified all the smears into benign and malignant lesion based on cell morphology. The criteria for benignancy were cohesive clusters, uniform appearing cells with bland nucleus, regular nuclear contour and fine chromatin. The criteria for malignancy were dyscohesive cells, cellular pleomorphism, nuclear enlargement, irregular nuclear shape, contour, chromatin irregularities, atypical mitotic figures and presence of necrosis.

So the final cytodiagnosis of the tumor was benign or malignant basaloid neoplasm of skin adnexal origin. No attempt was made for specific identification of tumors on cytology.

Excision biopsy of the lesion was done and the histological samples were processed and studied using standard procedures.

Light microscopic diagnosis of the slides were performed. Cytohistological correlations were attempted considering histological diagnosis as final.

\section{Results}

During the study period, a total of 2,400 cases of subcutaneous swellings were aspirated with adequate aspiration in 2000 cases. Among these cases, 20 cases were cytodiagnosed as basaloid tumors of skin adnexal origin accounting for $0.01 \%$ of neoplasms.

Majority of the cases occured in the adult and elderly age groups. $35 \%$ of the tumors (7 cases) occured in the $41-60$ year age group, $30 \%(6$ cases) in the 21-40 year age group and 25\%(5 cases) in the 61-80 year age group. The remaining $10 \%$ in the $0-20$ year age group.

In our study there was a male predilection accounting for $65 \%$ (13 cases). Females constituted 35\%(7 cases). The sites, in the descending order of their occurrence were-face, (6 cases), scalp (5 cases), extremities ( 4 cases), neck (3cases), chest ( 2 cases). The size of these tumors varied between one centimeter and four centimeters. 95\% (19 cases) of the swellings were slowly growing. Recurrance was seen in only one swelling (papillary digital adenocarcinoma). $65 \%$ of the cases occured in the subcutaneous plane and 35\% (7 cases) in the cutaneous plane. Cystic consistency was observed in 3 cases and tenderness was observed in 2 cases.

The 20 cases were cytodiagnosed as benign and malignant basaloid neoplasms of skin adnexal origin.
On histopathology, out of the 20 cases 12 were benign tumors and 8 were malignant tumors af skin adnexal origin. On histopathology, the benign tumors were nodular hidradenoma( 4 cases), spiradenoma( 4 cases), chondroid syringoma ( 2 cases), papillary eccrine adenoma(1 case) and cylindroma (1case). The malignant tumors were sweat gland adenocarcinoma (4 cases), digital papillary adenocarcinoma (2 cases), mucinous carcinoma of sweat gland ( 1 case) and cutaneous adenoid cystic carcinoma (1 case).

Table 2 shows the list of basaloid neoplasms with cytological features and their histopathological diagnosis.

\section{Discussion}

Eccrine sweat glands, which are appendages of the skin, start developing as early as the fourth gestational month, from the germ cells in the basal layer of the epidermis and are fully developed at the time of birth [1]. Eccrine glands are seen any where in the body but are particularly distributed in the palms and soles [1].

Eccrine glands are composed of three segments -intra epidermal duct or acrosyringium, intra dermal duct, and secretory coil lying in the lower half of dermis or between the dermis and subcutaneous fat [1]. The cytology of the eccrine glands consists of ductal epithelial cells, secretory cells, myoepithelial cells with spindle shaped nucleus, and long contractile fibrils and hyaline basement membrane and collagen fibrils [1-3]

Tumors of the eccrine gland can arise from any of the three segments of the eccrine gland mentioned above [2,3] (Table 3). Eccrine tumors of sweat gland can occur anywhere in the human body with a predilection to head and neck region, palms and soles, extremities and ventral surface of body [2-4]. Eccrine tumors have a wide range of age distribution starting in childhood and extending into adulthood with no particular sex distribution. They vary in size from few millimeters to several centimeters. They are solitary or multiple. They present as papules, nodules and cystic lesions. They are sessile or pedunculated. They occur in the cutaneous, dermal or in the subcutaneous plane. Spiradenoma present as painful masses. Secondary changes like ulceration, bleeding, pigmentation can occur.

\section{Eccrine spiradenomas}

Eccrine Spiradenomas was first described by Kersting and Helwig [4]. The cytology of these tumors has been described by Varsa et al. [5] and Kim [6]. It is similar to the one found in our study. The cytology consists of uniformly sized cuboid cells with scant cytoplasm, round

\section{Features \\ 1. Predominant cell \\ 2. Arrangement of cells \\ 3. Type of basaloid cells \\ 4. Other cells \\ 5. Back ground}

\section{Observations}

Basaloid - small round cells with deeply basophilic appearance due to aggregation of nuclei. Cohesive clusters, dyscohesive groups, papillary fragments, rosettes, glandular structures, acinar pattern, solitary cells.

a. Cells with scant cytoplasm with small dark nuclei

b. Cells with scant cytoplasm with large pale nucleus

c. Cuboidal cells with round nucleus and basophilic cytoplasm

d. Round cells with clear cytoplasm

a. Chondromyxoid - stromal fibrillary fragments with stain bluish pink to magenta with giemsa.

b. Heamorrhagic - blood mixed

c. Necrosis - necrotic material

d. Mucinous - mucin rich

Inflammatory cells - lymphocytes

f. Basement membrane material - acellular homogenous hyaline bands or globules

Table 1: Cytological observations in smears studied. 
Citation: Devanand B, Vadiraj P (2011) Fine Needle Aspiration Cytology of Eccrine Skin Adnexal Tumors. J Cytol Histol 2:129. doi:10.4172/21577099.1000129

Page 3 of 7

\begin{tabular}{|c|c|c|c|c|c|c|}
\hline SI No & No of Cases & Cellular arranmement & Type of basaloid cells & Background & $\begin{array}{l}\text { Cytological } \\
\text { diagnoses }\end{array}$ & $\begin{array}{l}\text { Histopathological } \\
\text { diagnoses }\end{array}$ \\
\hline 1 & 4 & Clusters and rosettes & $\begin{array}{l}\text { Uniform cuboid cells with } \\
\text { small dark nucleus and } \\
\text { large pale nucleus }\end{array}$ & $\begin{array}{l}\text { Diffuse lymphocytes, } \\
\text { occasional hyaline } \\
\text { eosinophilic material }\end{array}$ & Benign & Spiradenoma \\
\hline 2 & 4 & Tight clusters & $\begin{array}{l}\text { Small round cells with } \\
\text { clearcytoplasm and } \\
\text { polygonal cells with } \\
\text { basophilic cytoplasm }\end{array}$ & & Benign & Nodular hidradenoma \\
\hline 3 & 1 & Papillary fragments & Bland basaloid cells & $\begin{array}{l}\text { Fibrovascular core } \\
\text { traversing the cells }\end{array}$ & Benign & Papillary eccrine adenoma \\
\hline 4 & 2 & $\begin{array}{l}\text { Solitary cells scattered } \\
\text { throughout the smear }\end{array}$ & Bland basaloid cells & $\begin{array}{l}\text { Fibrillary } \\
\text { chondromyxoid stroma }\end{array}$ & Benign & Chondroid syringoma \\
\hline 5 & 1 & $\begin{array}{l}\text { Islands of cells } \\
\text { palisaded manner }\end{array}$ & $\begin{array}{l}\text { Bland basaloid cells Thick } \\
\text { hyaline globules }\end{array}$ & Thick hyaline globules & Benign & Cyloindroma \\
\hline 6 & 2 & $\begin{array}{l}\text { Syncytial aggregates. } \\
\text { Folding sheets }\end{array}$ & Pleomophic epithelial cells & $\begin{array}{l}\text { Fibrovascular core } \\
\text { traversing the cell } \\
\text { fragments }\end{array}$ & Malignant & $\begin{array}{l}\text { Digital papillary } \\
\text { adenocarcino ma }\end{array}$ \\
\hline 7 & 4 & $\begin{array}{l}\text { Clusters and galndular } \\
\text { structures }\end{array}$ & $\begin{array}{l}\text { Pleomorphic epithelial } \\
\text { cells, atypical mitotic } \\
\text { figures }\end{array}$ & Necrosis & Malignant & $\begin{array}{l}\text { Sweat gland adenocarcino } \\
\text { ma }\end{array}$ \\
\hline 8 & 1 & $\begin{array}{l}\text { Clusters and solitary } \\
\text { cells }\end{array}$ & $\begin{array}{l}\text { Epithelial cells with mild } \\
\text { nuclear pleomorphism }\end{array}$ & Mucin rich & Malignant & $\begin{array}{l}\text { Mucinous carcinoma of } \\
\text { sweat gland }\end{array}$ \\
\hline 9 & 1 & $\begin{array}{l}\text { Tridimensional globoid } \\
\text { clusters }\end{array}$ & Pleomorphic basaloid cells & $\begin{array}{l}\text { Eosinophilic acellular } \\
\text { homogenous sub- } \\
\text { stance }\end{array}$ & Malignant & $\begin{array}{l}\text { Cutaneous adenoid cystic } \\
\text { carcinoma }\end{array}$ \\
\hline
\end{tabular}

Table 2: Cytological features of benign and malignant basaloid neoplasms with their histopathological diagnoses.

\begin{tabular}{|l|l|l|}
\hline Intra epidermal duct & Intra dermal duct & Secretory coil \\
\hline 1) Syringoma & 1) Syringoma & 1) Spiradenoma \\
\hline 2) Clearcell acanthoma & 2) Spiradenoma & 2) Papillary eccrine adenoma \\
\hline 3) Intra epidermal epithelioma & 3) Chondroid syringoma & 3) Mucinous carcinoma \\
\hline 4) Poroma & 4) Cylindroma & 4) Digital papillary adenocarcinoma \\
\hline 5) Acrospiroma & 5) Sweat gland adenocarcinoma & \\
\hline
\end{tabular}

Table 3: Classification of eccrine gland tumours based on origin.

\begin{tabular}{|c|c|c|}
\hline Cell pattern / cytology & Eccrine tumors & Differential diagnosis \\
\hline Clear cells & Acrospiroma Syringomas poromas & $\begin{array}{l}\text { 1) Trichelemmoma } \\
\text { 2) Metastatic renal cell carcinoma } \\
\text { 3) Glomus tumor } \\
\text { 4) Balloon cell melanoma }\end{array}$ \\
\hline Basaloid cells & Poromas syringoma & $\begin{array}{l}\text { 1) Basal cell carcinoma } \\
\text { 2) Tricho epithelioma } \\
\text { 3) Seborrhoeic keratosis }\end{array}$ \\
\hline Rosette like formation & Spiradenoma & $\begin{array}{l}\text { 1) Subcutaneous metastasis } \\
\text { 2) Synovial sarcoma }\end{array}$ \\
\hline Papillary fragments & Papillary eccrine tumors & Cutaneous endometriosis \\
\hline Pleomorphic epithelial cells with glandular pattern & Sweat gland adenocarcinoma & Cutaneous metastases from the lungs, breast etc \\
\hline
\end{tabular}

Table 4: Cytological differential diagnosis of eccrine gland tumors.

to oval bland nucleus and inconspicuous nucleoli, arranged as tight multilayered clusters, tubules and rosette formation. The presence of scattered naked nuclei, spindle shaped myoepithelial cells and dense lymphocytic infiltrate distinguish this tumor cytologically from other eccrine tumors [7].

\section{Eccrine acrospiroma}

Eccrine Acrospiroma is also called as nodular hidradenoma. The cytology has been described by Punia et al. [8] and Kim et al. [9] .The cytology is similar to the one found in our study. These tumors are composed of tight clusters or sheets of small round cells with a dark nucleus, clear cytoplasm and distinct cell membrane and polygonal cells with a rounded nucleus and slightly basophilic cytoplasm. Transitional cells between these two varieties with eosinophilic cytoplasm, fragments of hyalinized stroma, keratinizing cells are present [2]

\section{Chondroid syringoma}

Chondroid Syringoma is described as mixed tumor of skin or pleomorphic sweat gland adenoma[10]. We have reported the cytological features of 2 cases. The cytology is composed of cuboidal epithelial cells, arranged as acini, groups, solitary cells, flattened myoepithelial cells, presence of cells with abundant hyaline cytoplasm [11]. The stroma varies from vaguely eosinophilic to basophilic representing loose reactive fibrous tissue, myxoid. tissue or solid 
Citation: Devanand B, Vadiraj P (2011) Fine Needle Aspiration Cytology of Eccrine Skin Adnexal Tumors. J Cytol Histol 2:129. doi:10.4172/21577099.1000129
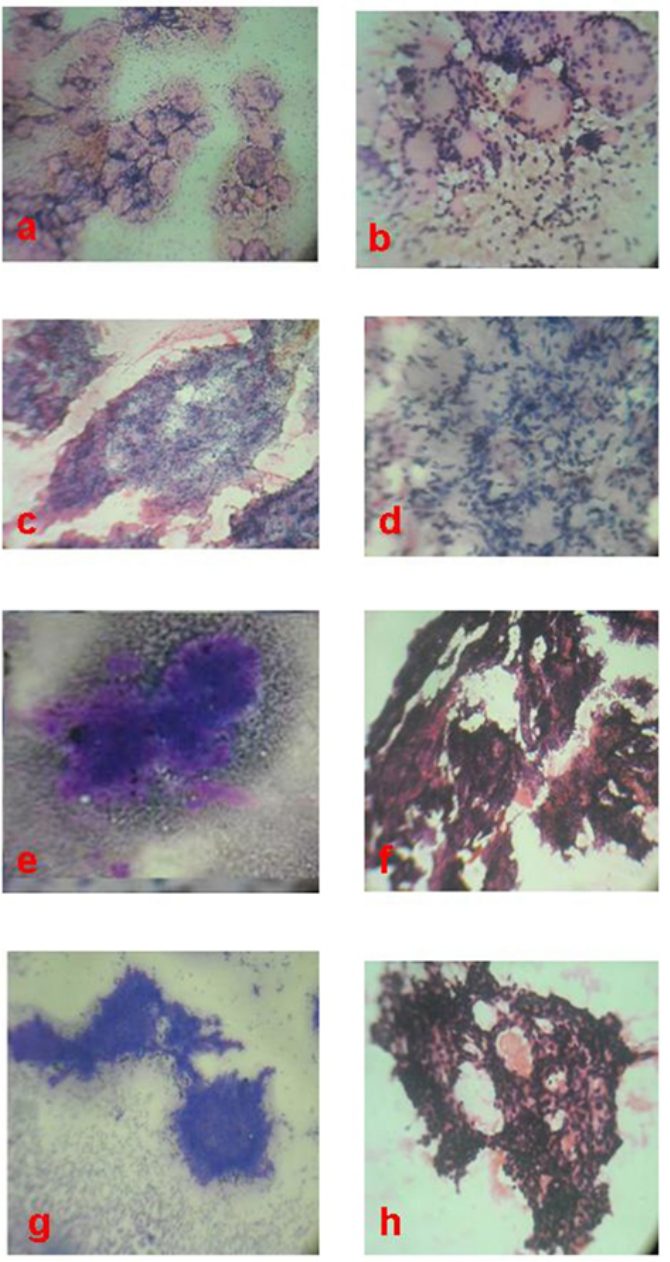

Figure 1: Cylindroma. (a and b) Smears showing islands of epithelial cells in a palisaded manner ( $\mathrm{H}$ and $\mathrm{E}, \mathrm{x} 100)$. and thick hyaline bands (H and $\mathrm{E}, \mathrm{x} 400)$. Chondroid syringoma (c, d and e) Smears showing bland basaloid cells scattered in a fibrillary chondroid stoma (H and E,x100, x 400, MGG,x100).

Papillary eccrine Adenoma.(f, g and h) Smears showing papillary fragments of bland basaloid cells fibro vascular core (H and E,x100, MGG,x100, H and E,x400).
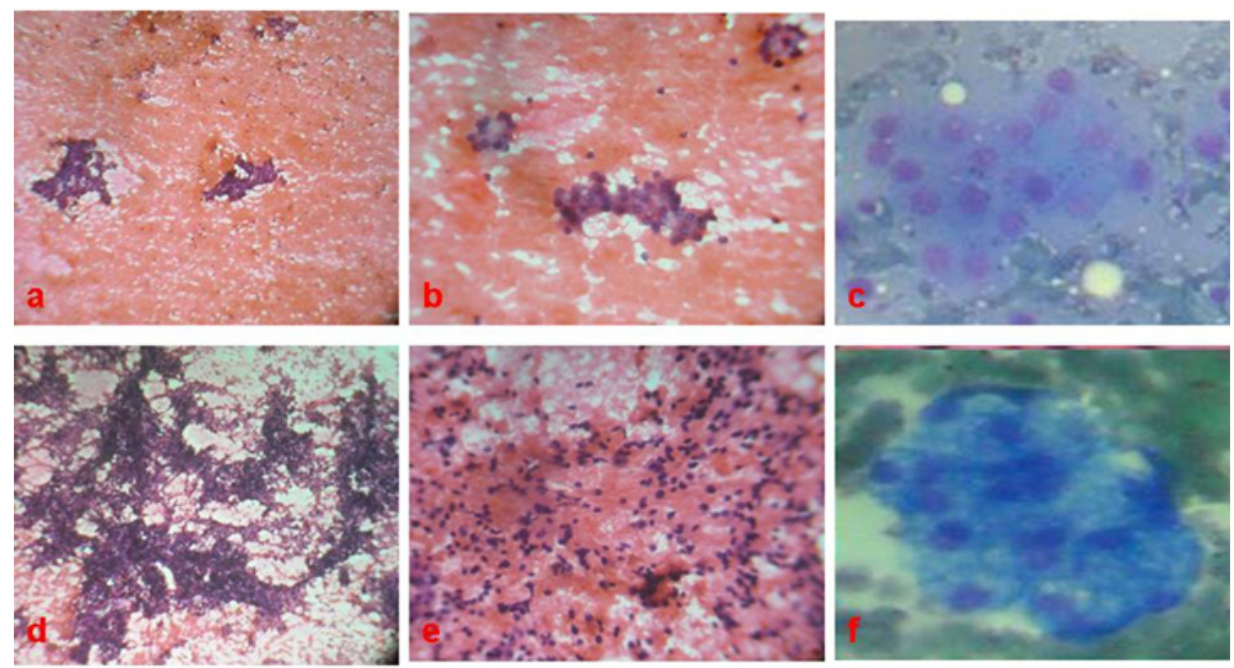

Figure 2: Eccrine Spiradenoma. (a, b and c) Smear showing uniform cuboid cells in chusters and rosette formation (H and E,x100, $H$ andE, $x 400, M G G \times 400)$ Nodular Hidradenoma (d, e and f) Smear showing tight clusters of a mixture of small round cells with clear cytoplasm and polygonal cells with basophilic cytoplasm $(\mathrm{H}$ and $\mathrm{E} \times 100, \mathrm{H}$ and $\mathrm{E} \times 400$, MGG $\times 400$ 
Citation: Devanand B, Vadiraj P (2011) Fine Needle Aspiration Cytology of Eccrine Skin Adnexal Tumors. J Cytol Histol 2:129. doi:10.4172/21577099.1000129
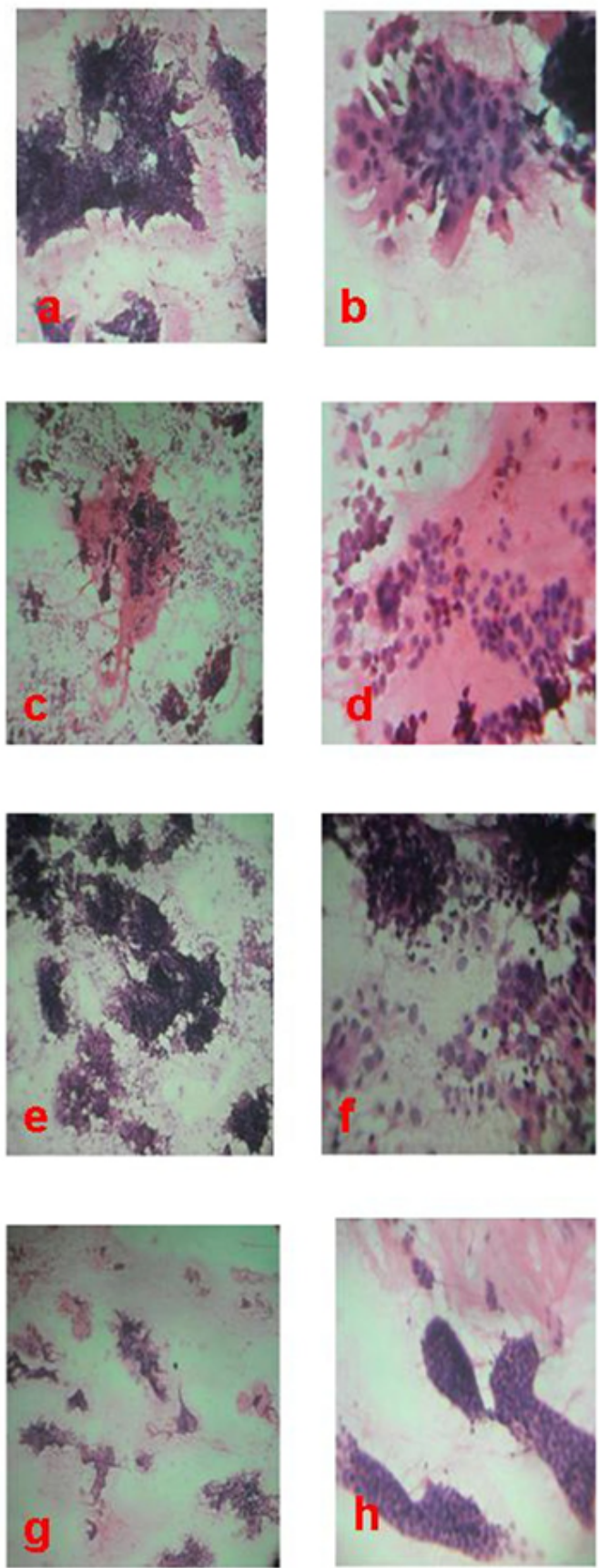

Figure 3: Sweat gland carcinoma. (a and b) Smear showing pleomorphic epithelial cells in clusters and glandular structures ( $\mathrm{H}$ and $\mathrm{E} \times \mathrm{100}, \mathrm{x} 400)$ Mucinous carcinoma of sweat gland. (c and d) Smear showing clusters of epithelial cells having mild nuclear pleomorphism in a lake of mucin ( $\mathrm{H}$ and $\mathrm{E} \times 100, \mathrm{x} 400)$ Digital papillary Adenocarcinoma.(e and f) Smear showing syncytial aggregates and folding sheets of pleomorphic epithelial cells traversed by fibro vascular core ( $\mathrm{H}$ and $\mathrm{E} \times 100, \mathrm{x}$ 400)

Cutaneous adenoid cystic carcinoma. ( $\mathbf{g}$ and $\mathbf{h}$ ) Smear showing tridimensional globoid clusters of pleomorphic basaloid cells and acellular basement membrane (H and $\mathrm{E} \times 100, \mathrm{x} 400)$

hyaline cartilage. Also observed are eosinophilic globules with radiating fibrillary structures.

\section{Papillary eccrine adenoma}

Papillary eccrine adenoma is an un common benign sweat gland tumor originally described in 1977 by Rulon and Helwig [14]. Cytologically, it is characterized by basaloid cells with scant cytoplasm and bland nucleus in papillary fragments. Eosinophilic fragments of fibrovascular core are also obsvered.

\section{Eccrine dermal cylindromas}

Eccrine dermal Cylindromas are also called turban tumors $[3,15]$ Cytologically these tumors are composed of islands of epithelial cells arranged in a palisaded manner. The cells are of 2 types - those with 
dark staining nuclei, and those with light staining nuclei. Thick hyaline bands made up of collagen fibrils which represent subepidermal lamina densa are seen within the cell cluster or separating them.

\section{Eccrine syringomas}

Eccrine syringomas consist of cords and groups of ductal epithelial cells with bland nucleus, groups of basaloid cells, vacuolated cells with keratohyaline granules, fragments of stromal tissue [2].

\section{Eccrine poromas}

Eccrine poromas are made up of uniform cuboidal or round epithelial cells with deeply basophilic nucleus in sheets, anastomozing bands and cords with intercellular bridges, clear cells and fragments of fibrovascular tissue [2].

Malignancy arising from eccrine glands constitute only a minute fraction of sweat gland neoplasms [3]. The malignant eccrine tumors can occur denovo or certain benign eccrine tumors of long standing duration transform into malignancy. Benign tumors like eccrine spiradenomas, acrospiromas, syringomas cylindromas can undergo malignant transformation [2,3]. Clinically, the transformation is heralded by rapid growth of a long standing cutaneous, nodule and attainment of large sizes. Cytologically, transformation is characterized by loss of nested or trabecular pattern of cell distribution, cellular atypia, nuclear pleomorphism and hyperchromasia, increased mitotic rate, necrosis and absence of dual cell population.

Sweat gland adenocarcinomas: are cytologically characterized by pleomorphic epithelial cells, predominantly dispersed, forming clusters and glandular structures [2]. The cells have moderate to abundant cytoplasm, large irregular nucleus with coarsely granular chromatin, containing visible nucleoli of various sizes. Atypical mitotic figures and necrosis may be seen $[16,17]$.

Mucinous or adenocystic carcinoma: is characterized by clusters of cohesive epithelial cells floating in lakes of mucin. The nuclear abnormalities like nuclear enlargement are slight. They have small nucleoli $[2,16,18]$.

Microcytic adnexal carcinoma: is cytologically characterized by clusters of uniform keratinocytes, pleomorphic epithelial cells with ductal differentiation and dense collagenous stromal fragments $[2,19,20]$.

Cutaneous adenoid cystic carcinoma: is characterized by epithelial cells and an acellular basement membrane material [21]. The epithelial cells are arranged in cohesive, often spherical or tridimensional globoid clusters of various sizes. They are relatively small with basaloid appearance, scant cytoplasm, and small but clearly visible nucleoli. The acellular homogeneous basement membrane substance are eosinophilic and transparent [2].

Digital papillary adenocarcinoma: The cytology of digital papillary adenocarcinoma shows tissue fragments consisting of syncytial aggregates and complex folded branching sheets of pleomorphic epithelial cells with a distinct anatomical border. The tissue fragments show nuclear crowding and overlapping. Fibrovascular core traverse or circumscribe the tissue fragments. The cells have enlarged ovoid pale nuclei, finely granular chromatin, distinct nucleoli and dense cytoplasm with distinct cell borders [22,23].

Recurrences occur in microcystic adnexal carcinoma, adenoid cystic carcinoma, digital papillary adenocarcinoma, porocarcinomas, mucinous adenocarcinoma, malignant spiradenoma and malignant hidradenoma $[2,3]$.

Malignant eccrine tumor the porocarcinomas, aggressive digital papillary adenocarcinomas, malignant hidradenomas metastasize to the regional lymph nodes and distant sites like lungs $[2,3]$.

The eccrine skin adnexal tumors have to be differentiated from other cutaneous and subcutaneous lesions having similar cytology (Table 4).

The diagnosis of eccrine tumors sometimes cannot be made with certainity on cytology or histology, in which case immunohistochemical differentiation of the eccrine tumors can be made[24]. CK7 (cytokeratin) and CD34 (cluter differentiation)are markers for secretory coil, CK6 and CK10 are markers for the straight portion of the eccrine duct and SMA (smooth muscle actin) and CD10 are markers for myoepithelial cells. Syringomas show positivity for CK6 and CK10 marker indicating that they arise from eccrine duct. Cylindromas and spiradenomas are positive for CK7 indicating that they arise from secretory coil.

\section{Conclusion}

Though there is paucity of case reports describing the cytomorphological features of eccrine tumors, fine needle aspiration can be used successfully as a very simple diagnostic investigation for eccrine skin adnexal tumors. In many cases it can exclude or confirm malignancy and in these instances help to outline surgical management.

\section{References}

1. Murphy GF (1997) Histology of skin. In Eder D, Elenitsas R, Jaworsky C Johnson B Editors. Lever Histopathology of skin $8^{\text {th }}$ ed. Philadelphia ; Lippincott -Raven. p24-28.

2. Elder D, Elenitsas R, Ragsdale BD (1997) Tumors of the epidermal appendages In : Elder D, Elenitsas R, Jaworsky C, Johnson B Editors. Lever Histopathology of skin $8^{\text {th }}$ ed. Philadelphia: Lippincott-Raven : p777-795.

3. Rosai J (2004) Skin In : Rosai and Ackerman's surgical pathology $9^{\text {th }}$ ed. St louis : Mosby. p140-145

4. Grekin RC, Samlaska CP, Vin-Christian K (2000) Epithelial nevi, Neoplasms and Cysts. In : Odom RB, James WD, Berger JG editors. Andrew's diseases of the skin (clinical dermatology) $9^{\text {th }}$ ed. Philadelphia : W.B. Sauders company : p845-855.

5. Varsa EW, Jordan SW (1990) Fine needle aspiration cytology of malignan spiradenoma arising in congenital eccrine spiradenoma. Acta Cytol 34: 275277

6. Kim DJ (2005) Fine needle aspiration cytology of eccrine spiradenoma ; report of a case. Korean J Cytopathol 16: 98-101.

7. Kolda TF, Ardaman TD, Schwartz MR (1997) Eccrine spiradenoma mimicking Adenoid Cystic carcinoma on fine needle aspiration : A case report. Acta Cyto 41: 852-858.

8. Punia RS, Hand U, Mohan H (2001) Fine needle aspiration cytology of Eccrine acrospiroma. Acta Cytol 45: 1083-1085.

9. Kim YO, Jeon CW, Chang HK (2005) Fine needle aspiration cytology of Eccrine acrospiroma of the breast. Report of a case misdiagnosed as ductal carcinoma Korean J cytopathol 16: 31-35.

10. Surana R, Molony R, Fitzgerald R (1993) Tumours of heterotopic salivary tissue in the upper cervical region in children. Surg Oncol 2: 133-136.

11. Hassab- el - Naby HM, Tam S, White WL, Ackerman AB (1989) Mixed tumors of the skin. A histological and immunohistochemical study. Am J Dermatapathol 11: $413-428$

12. Dominguez Iglesias $F$, Fresno Forcelledo $F$, Soler Sanchez $T$, Fernandez García L, Herrero Zapatero A (1990) Chondroid syringoma: A histological and immunohistochemical study of 15 cases. Histopathology 17: 311-317. 
Citation: Devanand B, Vadiraj P (2011) Fine Needle Aspiration Cytology of Eccrine Skin Adnexal Tumors. J Cytol Histol 2:129. doi:10.4172/21577099.1000129

13. Jyothi R Tanuja S (2001) Aspiration cytology in the diagnosis of primary tumors of skin adnexae. Acta Cytol 45: 805-886 (25ref), P 715-722

14. Rulon DB, Helwig EB (1977) Papillary eccrine adenoma. Arch Dermatol 113 596-598.

15. Crain RC, Helwig EB (1961) Dermal cylindroma (dermal eccrine cylindroma). Am J Clin Pathol 35: 504-515.

16. Yamamoto O, Nakayama K, Asali M (1992) Sweat gland carcinoma with mucinous and infiltrating duct like patterns. J Cutan Pathol 19: 334-339.

17. Mehregan AH, Hashimoto K, Rahbari H (1983) Eccrine adenocarcinoma. A clinicopathologic study of 35 cases. Arch Dermatol 119:104-114.

18. Mendoza S, Helwig EB (1971) Mucinous ( adenocystic ) carcinoma of the skin. Arch Dermatol 103: 68-78.

19. Chiller K, Passaro D, Scheuller M, Singer M, Mc Calmont T, et al. (2000)
Microcystic adnexal carcinoma- forty eight cases, their treatment and their outcome. Arch Dermatol 136: 1355-1359.

20. Goldstein DJ, Barr RJ, Santa Cruz DJ (1982) Microcystic adnexal carcinoma: a distinct clinicopathologic entity. Cancer 50: 566-572.

21. Cooper PH, Adelson GF, Holthaus WH (1984) Primary Cutaneous adenoid cystic carcinoma. Arch Dermatol 120: 774-777.

22. Duke WH, Sherrod TT, Lupton GP (2000) Aggressive digital papillary adenocarcinoma. (aggressive digital papillary adenoma and adenocarcinoma revisited). Am J Surg Pathol 24: 775-784.

23. Gangene N, Joshi D, Sharma SM (2008) Cytomorphological dianosis of malignant eccrine tumors : report of two cases. Diagn Cytopathol 36: 801-804.

24. Missall TA, Burkemper NM, Jensen SL, Hurley MY (2009) Immunohistochemical differentiation of four benign eccrine tumors. J Cutan Pathol 36:190-196. 